\title{
Magnetron-Sputtered Ni-Cr and Ti-Si Layers to Protect Ti-46Al-8Nb (at.\%) Substrates Against Gas Absorption
}

\author{
Marzena Mitoraj-Królikowska and Elzbieta Godlewska1
}

(Submitted August 13, 2018; in revised form June 10, 2019)

\begin{abstract}
$\mathrm{Ni}-\mathrm{Cr}$ and Ti-Si layers were deposited by magnetron sputtering on $\mathrm{Ti}-46 \mathrm{Al}-8 \mathrm{Nb}$ (at.\%) substrates to suppress penetration of gases, which brings about undesirable changes in mechanical properties. Alloy samples with and without surface protection were subjected to interrupted oxidation at elevated temperature $\left(700\right.$ and $800{ }^{\circ} \mathrm{C}$ ) for up to $300 \mathrm{~h}$. Selected mechanical properties as well as adhesion of surface layers were examined in the as-received and oxidized state. Analytical techniques used to characterize surfaces and cross sections of the samples included scanning electron microscopy and light microscopy, energydispersive $x$-ray spectroscopy, $x$-ray photoelectron spectroscopy and $x$-ray diffraction. Both investigated layers were sufficiently adherent and effective in hindering gas absorption at $700{ }^{\circ} \mathrm{C}$; however, only $\mathrm{Ni}-\mathrm{Cr}$ showed promising properties for higher-temperature applications.
\end{abstract}

Keywords magnetron-sputtered coatings, mechanical testing, oxidation, titanium aluminides

\section{Introduction}

Alloys based on titanium aluminides are reckoned promising lightweight materials (density of about $4.0 \mathrm{~g} / \mathrm{cm}^{3}$ ) with good mechanical properties and oxidation resistance (Ref 1-5). They might partly replace Ni-superalloys in gas turbine engines (Ref 6), contributing to a $20-30 \%$ reduction in total weight and remarkable decrease in fuel consumption. In spite of a number of interesting properties, the application of TiAl alloys is still limited because of their relatively low ductility at room temperature (Ref 7), insufficient oxidation resistance at temperatures exceeding $800{ }^{\circ} \mathrm{C}(\operatorname{Ref} 8)$ and abrupt embrittlement after short exposure to oxidizing environments at elevated temperatures (Ref 9, 10). Dramatic changes in tensile properties may be brought about by absorption of small-size impurities, such as oxygen, nitrogen, carbon or atoms of inert gases.

A lot of work has been done to enhance oxidation resistance at high temperature and prevent dissolution of gases (Ref 1113). Among these, the most common appeared alloying and surface treatment.

Over the years, various coating compositions and deposition processes were elaborated (Ref 14-17) to protect titanium aluminides from oxidation and inward diffusion of gases. Among the available techniques, magnetron sputtering is very interesting, because it allows to obtain high-quality surface layers with controllable properties (structure, thickness, etc.) in eco-friendly conditions (Ref 18).

The aim of this study was to apply magnetron-sputtered layers containing nickel and chromium or titanium and silicon

Marzena Mitoraj-Królikowska and Elzbieta Godlewska, Faculty of Materials Science and Ceramics, AGH University of Science and Technology, Al. Mickiewicza 30, 30-059 Krakow, Poland. Contact e-mails: mmitoraj@agh.edu.pl and godlewsk@agh.edu.pl.

\begin{tabular}{|ll|}
\hline \multicolumn{1}{|c|}{ List of Symbols } \\
\hline$\mu$ & Friction coefficient (-) \\
$E$ & Young's modulus (GPa) \\
$H_{\mathrm{IT}}$ & Indentation hardness (MPa) \\
$H_{\mathrm{max}}$ & Maximum penetration depth under a load of $10 \mathrm{mN}(\mathrm{nm})$ \\
$\mathrm{HV}$ & Vickers hardness (HV) \\
$I$ & Cathode current intensity (A) \\
$L_{\mathrm{c} 1}$ & Critical load for cohesive failure (N) \\
$L_{\mathrm{c} 2}$ & Critical load for adhesive failure (N) \\
$P$ & Cathode emission power (W) \\
$p_{\mathrm{Ar}}$ & Argon pressure (Pa) \\
$P_{\mathrm{max}}$ & Maximum load for delamination or chipping of the coating \\
& (N) \\
$t$ & Coating deposition time (s) \\
$T$ & Temperature ( $\left.{ }^{\circ} \mathrm{C}\right)$ \\
& \\
\hline
\end{tabular}

on the surface of Ti-46Al-8 $\mathrm{Nb}$ (at.\%) substrates and assess their adhesion, ductility and protective properties. Chemical compositions of layers were selected so as to hamper dissolution of gases in the alloy at moderate temperatures and prevent oxidation at temperatures exceeding $700{ }^{\circ} \mathrm{C}$. The layers based on Ni-Cr and Ti-Si were expected to chemically bond oxygen and convert into relatively thin ceramic layers playing a role of diffusion barriers.

\section{Experimental}

The substrate used in this work, Ti-46Al-8Nb (at.\%), was a fully lamellar two-phase alloy: $\gamma$-TiAl $\left(75 \mathrm{~mol} \%\right.$ ) and $\alpha_{2}-\mathrm{Ti}_{3} \mathrm{Al}$ (25 mol.\%). The details of surface preparation and PVD equipment were described in our previous paper (Ref 17). The process parameters are listed in Table 1. The intended thickness of surface layers, about 1-2 $\mu \mathrm{m}$, was controlled exclusively by varying the deposition time. 
Target, $50 \mathrm{~mm}$ in diameter and composition Ti-10Si (at.\%), was made by hot pressing of elemental powders mixed in suitable proportions. Consolidation of powders required the pressure of $25 \mathrm{MPa}$ and temperature of $1300{ }^{\circ} \mathrm{C}$. The Ni-20Cr (at.\%) target was commercially available.

After deposition, the samples were subjected to cyclic oxidation in air at 700 or $800{ }^{\circ} \mathrm{C}$ for 80 or $300 \mathrm{~h}$ (Ti-Si only). Composition of as-deposited Ti-Si layers was the same as that of the target and slightly different (Ni-27Cr in at.\%) for the $\mathrm{Ni}$ $\mathrm{Cr}$ layers. The duration of each cycle at high temperature was $1 \mathrm{~h}$ (1-h cycles). The exact testing procedure has been described elsewhere (Ref. 17). To avoid losing some oxidation products which might chip off as a result of thermal shocks, the samples were held in alumina crucibles. Mass changes were recorded once a day by weighing samples with and without the crucibles (gross mass and net mass, respectively).

Micromechanical testing was done in agreement with ISO 14577-1, ISO 14577-2, PN-EN ISO 6507-1:2005 on as-coated and oxidized samples, by means of a CSEM Micro-Combi Tester (MCT), with the following fixed parameters: maximum load $10 \mathrm{mN}$ and loading rate $20 \mathrm{mN} / \mathrm{min}$. The properties evaluated in this test comprised maximum penetration depth of the indenter $\left(H_{\max }\right)$, Vickers hardness $(\mathrm{HV})$, indentation hardness $\left(H_{\mathrm{IT}}\right)$ and Young's modulus $(E)$. Adhesion of surface layers was determined in a scratch test using Rockwell $\mathrm{C}$ diamond intender. The maximum load applied was $30 \mathrm{~N}\left(P_{\max }\right)$, and the loading rate was $10 \mathrm{mN} / \mathrm{min}$. Failure phenomena were detected by in situ recording friction, acoustic emission and microscopic examination of the scratch track. Normal forces which brought about first symptoms of failure were referred to as critical loads $L_{\mathrm{c} 1}$ and $L_{\mathrm{c} 2}$, corresponding to the cohesive and adhesive failure, respectively.

\section{Results}

\subsection{Ni-Cr Layers}

The as-deposited Ni-Cr layers had smooth surface with a metallic luster. The oxidation behavior of these samples was tested in air at 700 and $800{ }^{\circ} \mathrm{C}$ during $80 \mathrm{~h}$. Net mass changes of alloy samples with and without the $\mathrm{Ni}-\mathrm{Cr}$ layers are presented in Fig. 1. It can be seen that net mass changes of the samples with the Ni-Cr layers are slightly higher than those of bare alloy. Scale spallation was not observed.

Morphology and composition of the scales formed on bare alloy and Ni-Cr layers were obviously different (Fig. 2). The surface of the Ni-Cr layers oxidized at 700 and $800{ }^{\circ} \mathrm{C}$ was smooth and covered with small and uniformly distributed crystals, larger than on the bare alloy. Underneath there was a zone with niobium-rich intermetallic precipitates and aluminum oxide embedded in a titanium-rich nitride phase (Ref 21).

Cross sections of the samples with Ni-Cr layers in Fig. 3 reveal an interdiffusion zone under the oxide scale. Thickness of the scale after $80 \mathrm{~h}$ of oxidation at 700 and $800{ }^{\circ} \mathrm{C}$ is about 2 $\mu \mathrm{m}$, whereas the interdiffusion zone at $800{ }^{\circ} \mathrm{C}$ is more than twice as thick as at $700^{\circ} \mathrm{C}$. In the diffusion zone, all alloy components ( $\mathrm{Ti}, \mathrm{Al}$ and $\mathrm{Nb}$ ) were found accompanied by nickel. The concentration of nickel decreased with the increasing distance from the surface which indicated inward diffusion of this element. Chromium was located mainly in the "oxide" layer. Oxidation of bare Ti-46Al-8Nb (at.\%) proceeded differently, as described in our previous papers (Ref 19-21). Three layers could be distinguished in the scale formed at $800{ }^{\circ} \mathrm{C}$ : very thin outer layer of $\mathrm{Al}_{2} \mathrm{O}_{3}$, subjacent layer of $\mathrm{TiO}_{2}$ with some niobium and inner mixed-oxide layer containing all alloy components.

The early stages of oxidation were analyzed by XPS. As can be seen in Table 2, composition of the surface was different for the $\mathrm{Ni}-\mathrm{Cr}$ layer and bare alloy after the same oxidation time. After $2 \mathrm{~h}$ of exposure, the amount of aluminum on alloy surface was twice higher compared with the Ni-Cr layer, whereas the amount of titanium was similar in both cases. In the case of samples with the Ni-Cr layers, the amounts of nickel and aluminum were similar and about twice higher than that of titanium. After $24 \mathrm{~h}$ of exposure, the amount of aluminum on the surface increased, indicating an outward diffusion of this element from the underlying alloy. The amount of titanium on the surface of bare alloy decreased after a longer oxidation time and was the same as for the sample with the Ni-Cr layer. The amount of nickel was slightly lower after $24 \mathrm{~h}$ of oxidation.

XRD patterns taken from the surface of Ti-46Al-8Nb (at.\%) with $\mathrm{Ni}-\mathrm{Cr}$ layers oxidized at 700 and $800{ }^{\circ} \mathrm{C}$ are presented in Fig. 4. Depending on the oxidation temperature, the sample surface had different morphology (Fig. 2) and composition (Fig. 4). The diffractogram of the sample oxidized at $700{ }^{\circ} \mathrm{C}$ (Fig. 4) showed only one oxide phase, i.e. $\mathrm{Cr}_{2} \mathrm{O}_{3}$, and small

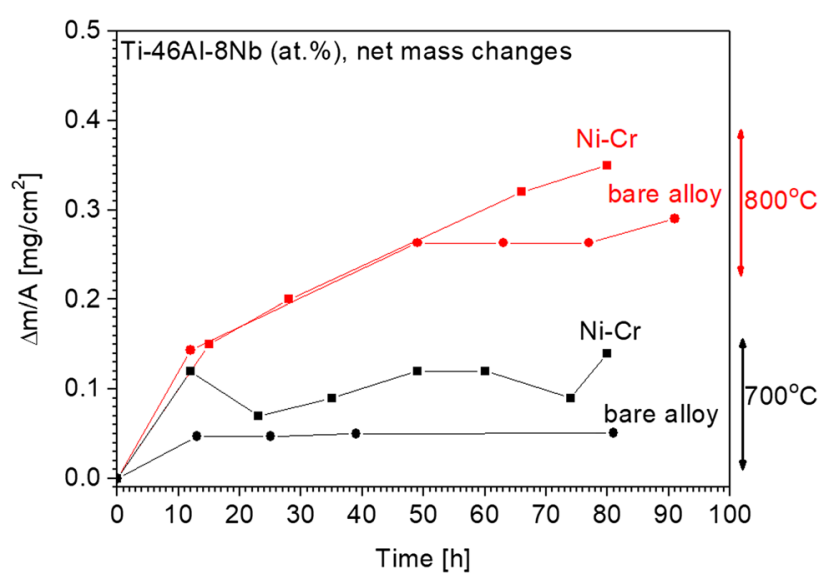

Fig. 1 Net mass changes of the Ti-46Al-8Nb (at.\%) samples with and without the $\mathrm{Ni}-\mathrm{Cr}$ layers on the surface upon oxidation in air at 700 and $800{ }^{\circ} \mathrm{C}$ (1-h cycles)

Table 1 Deposition parameters $\left(p_{\text {Ar }}\right.$-argon pressure; $I$ - cathode current intensity; $t$ - deposition time; $T$ - temperature, $P$-cathode emission power)

\begin{tabular}{lcccrr}
\hline Target, at.\% & $\boldsymbol{p}_{\text {Ar }}, \mathbf{P a}$ & $\boldsymbol{I}, \mathbf{A}$ & $\boldsymbol{t}, \mathbf{s}$ & $\boldsymbol{T},{ }^{\circ} \mathbf{C}$ & $\boldsymbol{P}, \mathbf{W}$ \\
\hline Ni-20Cr & 0.4 & 0.4 & 1800 & 260 & 360 \\
Ti-10Si & 7.5 & 0.4 & 1800 & 280 & 370 \\
\hline
\end{tabular}




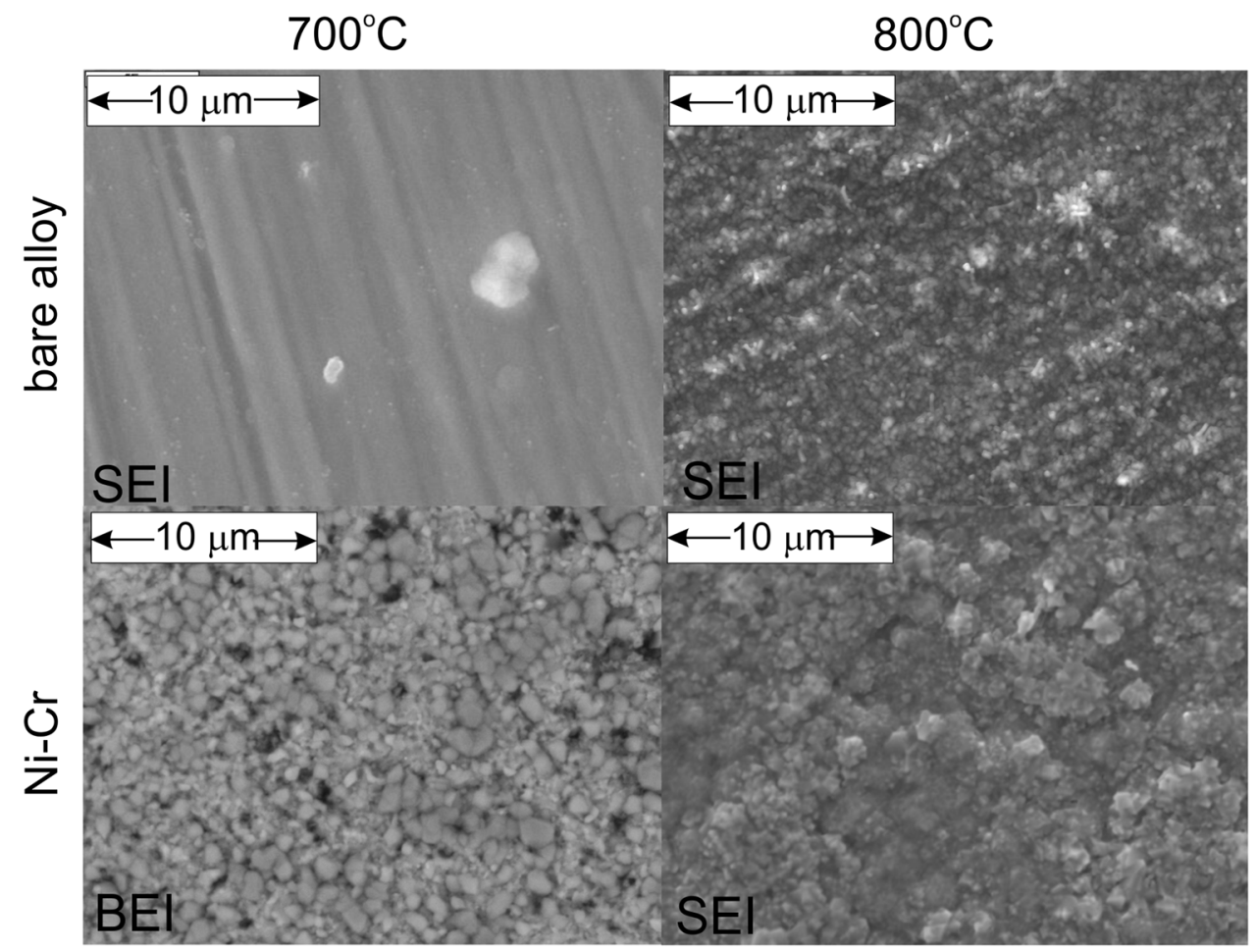

Fig. 2 Micrographs (SEM SEI/BEI) of sample surfaces after $80 \mathrm{~h}$ of oxidation in air at 700 and $800{ }^{\circ} \mathrm{C}(1-\mathrm{h}$ cycles)

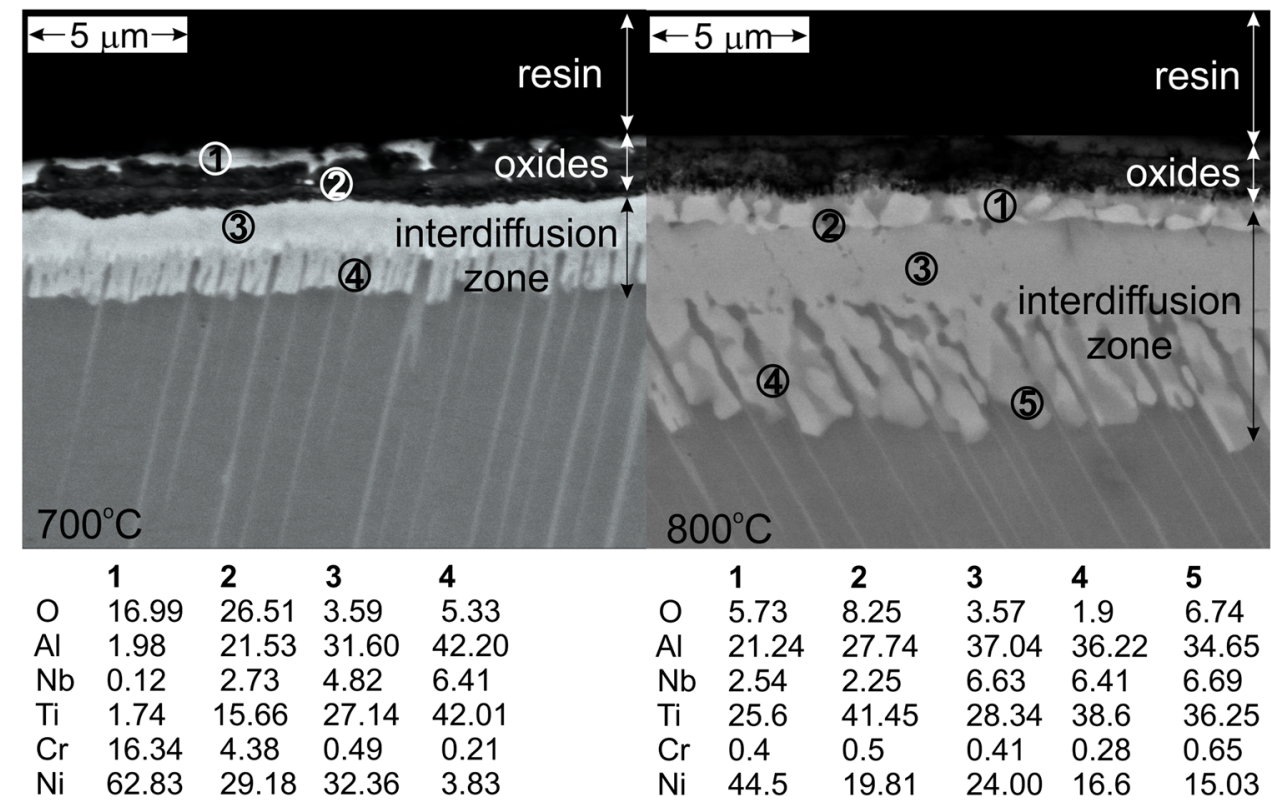

Fig. 3 Cross-sectional micrographs (SEM BEI) of Ti-46Al-8Nb (at.\%) samples with Ni-Cr layers oxidized for $80 \mathrm{~h}$ in air at 700 and $800{ }^{\circ} \mathrm{C}$ (1-h cycles)

Table 2 Surface composition (XPS) of bare Ti-46Al-8Nb (at.\%) alloy and alloy with a Ni-Cr layer after oxidation in air at $700{ }^{\circ} \mathrm{C}$ for 2 and $24 \mathrm{~h}$

\begin{tabular}{lcccccc}
\hline Samples & Oxidation time, $\mathbf{h}$ & Al, at.\% & Ti, at.\% & Nb, at.\% & Ni, at.\% & Cr, at.\% \\
\hline Bare alloy & 2 & 81 & 16 & 3 & $\ldots$ & $\ldots$ \\
Ni-Cr/alloy & 2 & 46 & 14 & 0 & 39 & Traces \\
Bare alloy & 24 & 95 & 4 & 1 & $\ldots$ \\
Ni-Cr/alloy & 24 & 58 & 14 & 0 & 28 & Traces \\
\hline
\end{tabular}


amounts of $\mathrm{AlNi}_{2} \mathrm{Ti}$ and $\mathrm{Ni}$. During oxidation at $800{ }^{\circ} \mathrm{C}$, the following oxides were formed: $\mathrm{NiO}, \mathrm{NiTiO}_{3}, \mathrm{Cr}_{2} \mathrm{O}_{3}$ and $\mathrm{TiO}_{2}$.

Micromechanical properties of samples with the $\mathrm{Ni}-\mathrm{Cr}$ layers are collected in Table 3. The highest value of penetration depth at the maximum load of $10 \mathrm{mN}$ was found for the unoxidized sample, and it decreased after oxidation. Vickers hardness $(\mathrm{HV})$ and indentation hardness $\left(H_{\mathrm{IT}}\right)$ were the lowest for the unoxidized layer and increased with the oxidation temperature. The sample oxidized at $800{ }^{\circ} \mathrm{C}$ had the highest Young's modulus.

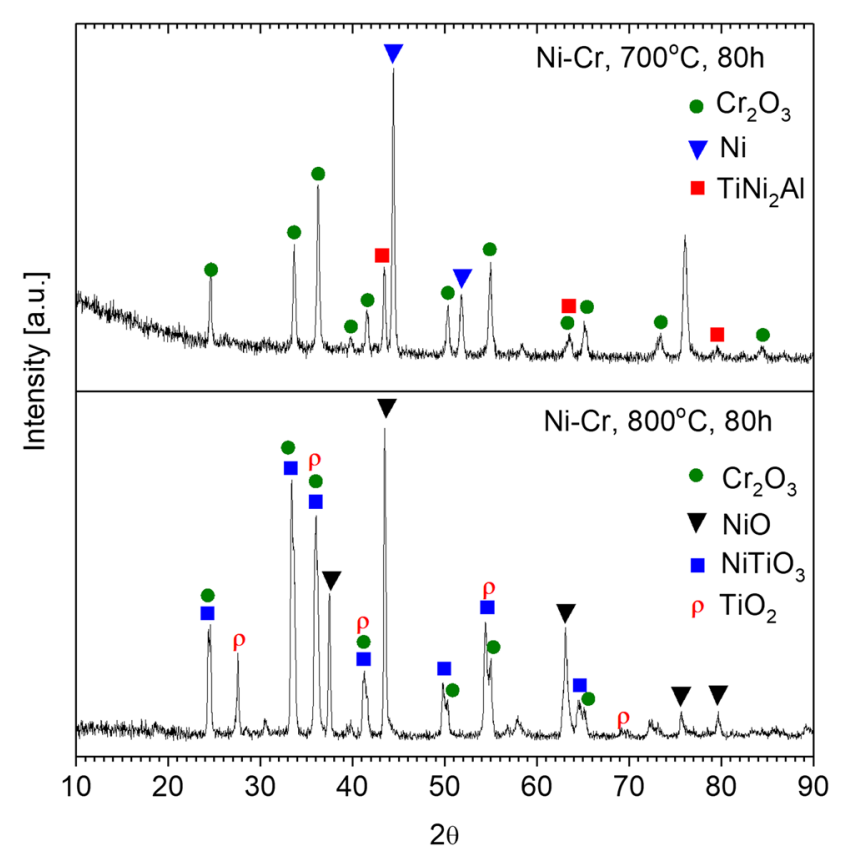

Fig. 4 XRD patterns from the surface of Ti-46Al-8Nb (at.\%) samples with Ni-Cr layers oxidized at 700 and $800{ }^{\circ} \mathrm{C}$ for $80 \mathrm{~h}(1-\mathrm{h} \mathrm{cy}$ cles)
The results of scratch test are presented in Table 4 . The Ni$\mathrm{Cr}$ layers before and after oxidation had good adhesion. The load which caused cohesive cracks inside the scratch track $\left(L_{\mathrm{c} 1}\right)$ was higher for the oxidized samples. The critical load for adhesive failure $\left(L_{\mathrm{c} 2}\right)$ exceeded $30 \mathrm{~N}$ for the unoxidized layer and was about $26 \mathrm{~N}$ for the oxidized ones. However, after oxidation at $800{ }^{\circ} \mathrm{C}$ slightly worse adhesion was noted-cracks and delamination were observed close to the scratch track (Fig. 5b).

\subsection{Ti-Si Layers}

Ti-46Al-8Nb (at.\%) samples with Ti-Si (at.\%) layers were oxidized at 700 or $800{ }^{\circ} \mathrm{C}$ for 80 or $300 \mathrm{~h}$. Net mass changes over the oxidation time, shown in Fig. 6, were very similar for bare alloy and alloy with the deposited layer at $700{ }^{\circ} \mathrm{C}$ (black lines). At $800{ }^{\circ} \mathrm{C}$ the net mass changes of samples with the TiSi layer after 80 and $300 \mathrm{~h}$ of oxidation were about three times higher compared with the bare alloy.

Surfaces of the alloy samples with and without Ti-Si layers after 80 and $300 \mathrm{~h}$ of oxidation at $700{ }^{\circ} \mathrm{C}$ were microscopically smooth. In contrast, as illustrated in Fig. 7, at $800{ }^{\circ} \mathrm{C}$ the size of crystals growing on the surface of a Ti-Si layer increased with the oxidation time. The oxide layer on the surface of bare alloy remained fine crystalline even after $300 \mathrm{~h}$ of exposure.

XRD analyses from the surface of sample oxidized at $800{ }^{\circ} \mathrm{C}$ (Fig. 8) revealed $\mathrm{TiO}_{2}$ (rutile) as the predominant phase as well as small amounts of $\mathrm{Al}_{2} \mathrm{O}_{3}$ (corundum) and $\mathrm{SiO}_{2}$ (quartz). The large crystals in Fig. 7 are built of rutile. EDS analysis from the surface of sample with the Ti-Si layer oxidized at $800{ }^{\circ} \mathrm{C}$ for $300 \mathrm{~h}$ showed titanium, aluminum and oxygen only.

Cross sections of samples with a Ti-Si layer after $80 \mathrm{~h}$ of oxidation at different temperatures are compared in Fig. 9. At $700{ }^{\circ} \mathrm{C}$, the Ti-Si layer provided good protection to the alloy. The scale was thin and adherent, and there was no evidence of interdiffusion or phase transformations in the subjacent alloy. After the exposure at $800{ }^{\circ} \mathrm{C}$ the structure of the near-surface area became more complex. The scale was thick (about $10 \mu \mathrm{m}$ ) and layered. According to EDS, the surface was rich in

Table 3 Maximum penetration depth $\left(H_{\text {max }}\right)$, Vickers hardness $(\mathrm{HV})$, indentation hardness $\left(H_{\mathrm{IT}}\right)$ and Young's modulus (E) for Ti-46Al-8Nb (at.\%) samples with a $\mathrm{Ni}-\mathrm{Cr}$ layer

\begin{tabular}{|c|c|c|c|c|}
\hline Surface condition & $H_{\max }, \mathbf{n m}$ & HV & $H_{\mathrm{IT}}, \mathrm{MPa}$ & $E, \mathbf{G P a}$ \\
\hline Unoxidized & $240 \pm 8$ & $643 \pm 53$ & $6798 \pm 566$ & $207 \pm 27$ \\
\hline Oxidized for $300 \mathrm{~h}$ at $700^{\circ} \mathrm{C}$ & $236 \pm 16$ & $670 \pm 97$ & $7083 \pm 1026$ & $159 \pm 26$ \\
\hline Oxidized for $300 \mathrm{~h}$ at $800^{\circ} \mathrm{C}$ & $201 \pm 22$ & $1054 \pm 223$ & $11146 \pm 2359$ & $283 \pm 70$ \\
\hline
\end{tabular}

Table 4 Critical loads $\left(L_{\mathrm{c} 1}, L_{\mathrm{c} 2}\right)$ and friction coefficient $(\mu)$ in a scratch test for the Ti-46Al-8Nb (at.\%) alloy with Ni-Cr layers (maximum load $P_{\max }=30 \mathrm{~N}$ )

\begin{tabular}{|c|c|c|c|}
\hline Surface condition & $L_{\mathrm{c} 1}, \mathbf{N}$ & $L_{\mathrm{c} 2}, \mathrm{~N}$ & $\mu$ \\
\hline $\begin{array}{l}\text { Unoxidized } \\
\text { Oxidized for } 80 \mathrm{~h} \text { at } 700{ }^{\circ} \mathrm{C} \\
\text { Oxidized for } 80 \mathrm{~h} \text { at } 800{ }^{\circ} \mathrm{C}\end{array}$ & $\begin{array}{l}10.6 \pm 1.8^{(1)} \\
16.9 \pm 1.5^{(2)} \\
19.0 \pm 0.4^{(2)}\end{array}$ & $\begin{array}{l}>30 \\
26.2 \pm 1.3^{(3)} \\
26.0 \pm 2.5^{(4)}\end{array}$ & $\begin{array}{l}0.16 \pm 0.01 \\
0.18 \pm 0.02 \\
0.18 \pm 0.01\end{array}$ \\
\hline \multicolumn{4}{|c|}{$\begin{array}{l}\text { (1) Small cracks inside the scratch track propagating outwards, large crack at a load of } 16 \text { N; no delamination } \\
\text { (2) Cohesive failure (cracks) inside the scratch track (Fig. } 5(a, b) \text { ) } \\
\text { (3) Local chipping of the coating/oxide layer; no delamination or cracks (Fig. 5a) } \\
\text { (4) Cracks and delamination on both sides of the scratch track (Fig. 5b) }\end{array}$} \\
\hline
\end{tabular}



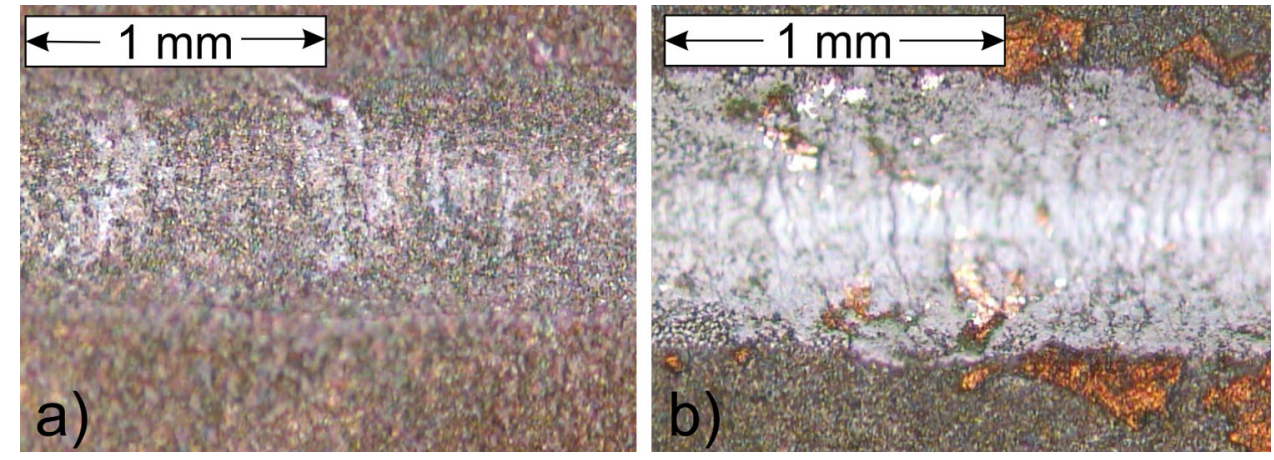

Fig. 5 Microscopic image of the scratch track on Ti-46Al-8Nb (at.\%) samples with Ni-Cr layers after $80 \mathrm{~h}$ of oxidation at (a) $700{ }^{\circ} \mathrm{C}$ and (b) $800{ }^{\circ} \mathrm{C}$

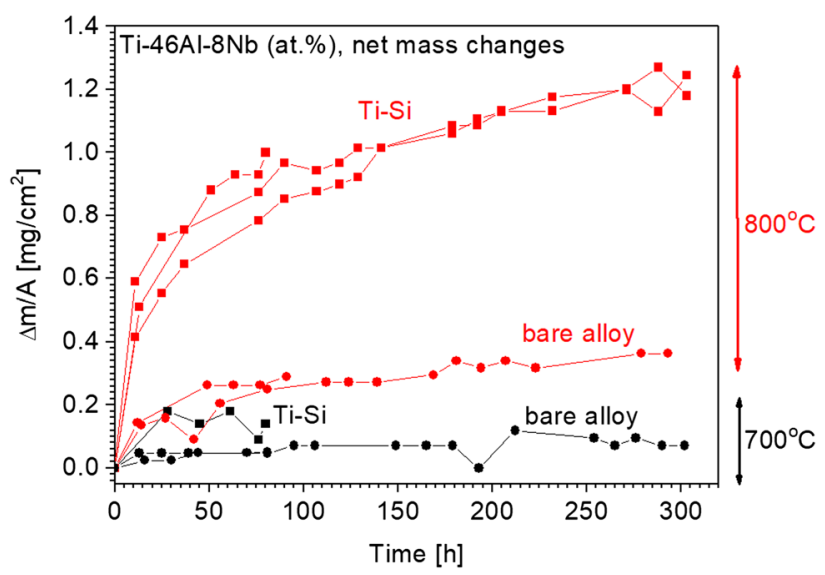

Fig. 6 Net mass changes of Ti-46Al-8Nb (at.\%) samples with and without Ti-Si layers on the surface upon oxidation in air at 700 and $800{ }^{\circ} \mathrm{C}$ (1-h cycles)

aluminum and oxygen $\left(\mathrm{Al}_{2} \mathrm{O}_{3}\right.$, confirmed by XRD). The scale was built of titanium, aluminum, silicon and oxygen in different proportions, depending on the location. Close to the scale/alloy interface, there were light-gray and dark-gray precipitates oriented perpendicularly to the substrate (BE image). The lighter precipitates were rich in niobium, whereas the darker ones in aluminum.

Oxidation at $800{ }^{\circ} \mathrm{C}$ caused changes in the micromechanical properties of the Ti-Si layer. As shown in Table 5, hardness decreased about three times and the values of Young's modulus were also lower compared with the unoxidized state. In general, the Ti-Si layers were brittle and prone to delamination. Results of scratch test in Table 6 indicate very low critical loads $\left(L_{\mathrm{c} 1}\right.$, $L_{\mathrm{c} 2}$ ) when referred to other layer investigated in this work (Table 4). Cracking and delamination of the Ti-Si layer around the scratch track are clearly visible in Fig. 10.

\section{Discussion}

\subsection{Ni-Cr Layers}

The principal idea of using Ni-Cr layers was to protect the Ti-46Al-8Nb (at.\%) alloy against gas absorption and oxidation in air. Ni-Cr based coatings are used to improve corrosion and oxidation resistance of steels (Ref 22) and Ti-based alloys (Ref 23). The relatively fast growing non-stoichiometric oxide $\mathrm{Ni}_{1}$ ${ }_{-y} \mathrm{O}$ with defects in the cation sublattice can hinder an inward diffusion of oxygen. The second oxide, $\mathrm{Cr}_{2} \mathrm{O}_{3}$, also defected within the cation sublattice has very low oxygen diffusivity. Doping of nickel (II) oxide with chromium leads to an increased concentration of cation vacancies. For illustration, the $\mathrm{NiO}$ layer on a $\mathrm{Ni}-16.3 \mathrm{Cr}$ (at.\%) coating contained $0.25-1.5$ wt. \% chromium (depending on the temperature and oxidation time) which increased the cation vacancy concentration in this layer (Ref 24). The oxidation behavior of $\mathrm{Ni}-\mathrm{Cr}$ coatings depends on many parameters, such as chromium concentration, deposition method and diffusion phenomena in the coating and the substrate. Thermodynamically $\mathrm{Cr}_{2} \mathrm{O}_{3}$ is more stable than $\mathrm{NiO}$ but in the real oxidation conditions other factors, e.g., transport properties, may decide about the composition and microstructure of the oxide layer. For illustration, during oxidation of $\mathrm{Ni}-\mathrm{Cr}$ alloys, containing approximately 10-20 wt.\% (11.1-22.0 at.\%) chromium, protective $\mathrm{Cr}_{2} \mathrm{O}_{3}$ oxide can form, but the concentration of more than about $20 \mathrm{wt} \%$ (22 at.\%) of $\mathrm{Cr}$ is necessary to secure growth of a continuous $\mathrm{Cr}_{2} \mathrm{O}_{3}$ layer (Ref 25). At lower concentrations, 10-20 wt.\% Cr, the scale consists of a mixture of $\mathrm{Cr}_{2} \mathrm{O}_{3}, \mathrm{NiO}$ and a $\mathrm{NiCr}_{2} \mathrm{O}_{4}$ spinel. $\mathrm{NiCr}_{2} \mathrm{O}_{4}$ can be formed when the concentration of chromium in $\mathrm{NiO}$ exceeds the solubility limit, which at $850{ }^{\circ} \mathrm{C}$ is reached around $1 \mathrm{wt} . \% \mathrm{Cr}$ or even less. $\mathrm{NiCr}_{2} \mathrm{O}_{4}$ can be also produced in a solid state reaction between $\mathrm{NiO}$ and $\mathrm{Cr}_{2} \mathrm{O}_{3}$ ( $\mathrm{Ref} 25$ ). Compositions of oxide scales on Ni-Cr layers with 20, 40, 60 and 80 at.\% Ni were studied in a work devoted to oxidation protection of Ti-6Al-4 V (at.\%) at the temperature of 750, 850 or $950{ }^{\circ} \mathrm{C}(\operatorname{Ref} 26)$. It has been shown that independently of the temperature and coating composition ( $\mathrm{Cr}$ concentration) the scale was built of two oxides: $\mathrm{Cr}_{2} \mathrm{O}_{3}$ and $\mathrm{NiO}$ but in different proportions and morphology (continuous single-phase or mixed-oxide layers). The best protection was provided when the concentration of chromium exceeded 60 at. $\%$ and a continuous layer of $\mathrm{Cr}_{2} \mathrm{O}_{3}$ formed on the surface (Ref 26).

In this work, the net mass changes of Ti-46Al-8 Nb (at.\%) samples with $\mathrm{Ni}-\mathrm{Cr}$ layers were slightly larger than for the bare alloy (Fig. 1). It should be underlined, however, that these mass changes were related to the formation of different oxides. According to the XPS (Table 2), $\mathrm{Al}_{2} \mathrm{O}_{3}$ and $\mathrm{NiO}$ might appear at the early stages of oxidation. $\mathrm{Al}_{2} \mathrm{O}_{3}$ was also found in the outermost part of the scale after $300 \mathrm{~h}$ of oxidation at 700 and $800{ }^{\circ} \mathrm{C}$. 


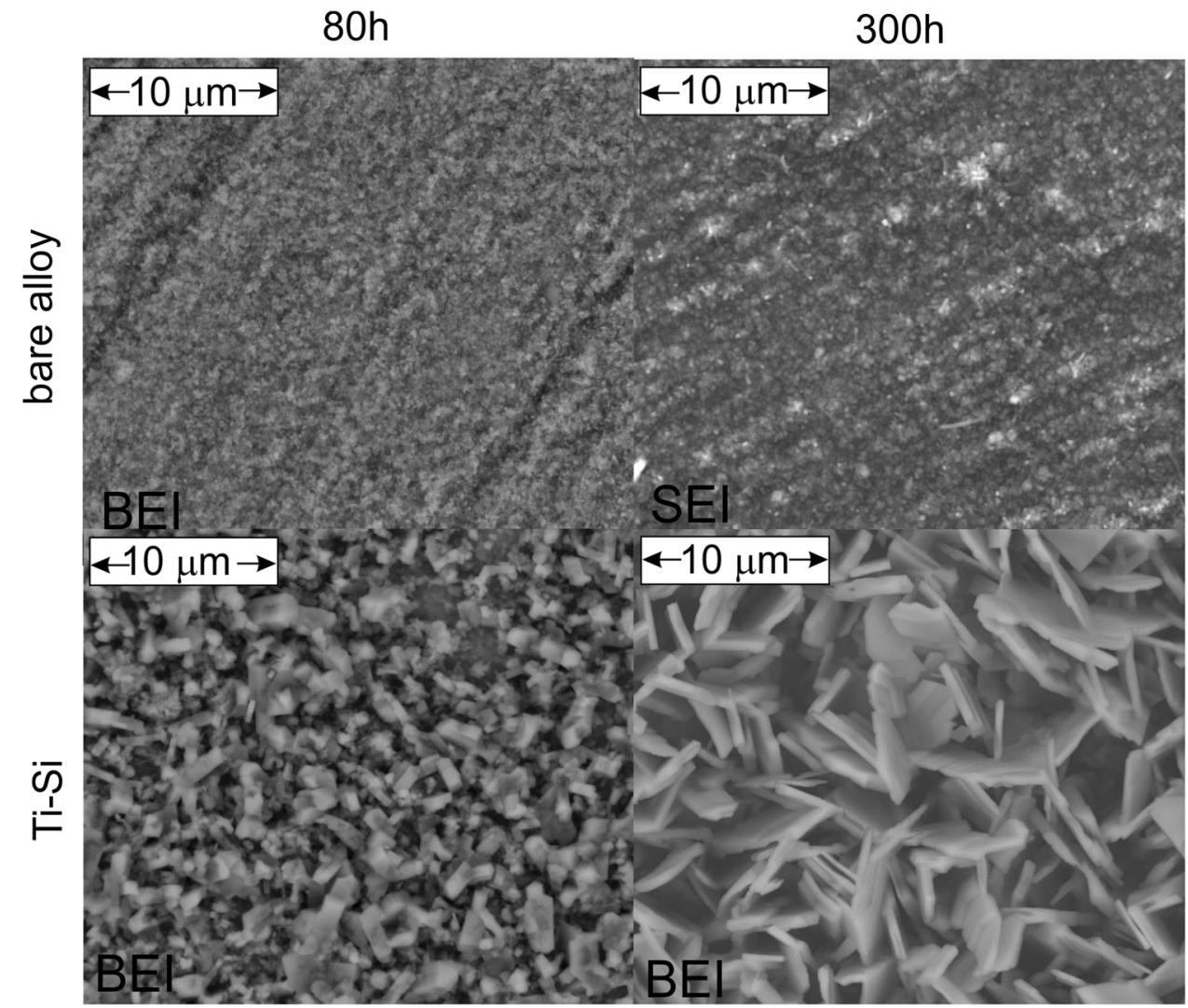

Fig. 7 Micrographs (SEM SEI/BEI) of the Ti-46Al-8Nb (at.\%) samples with and without Ti-Si layers on the surface after 80 and $300 \mathrm{~h}$ of oxidation in air at $800{ }^{\circ} \mathrm{C}(1-\mathrm{h}$ cycles $)$

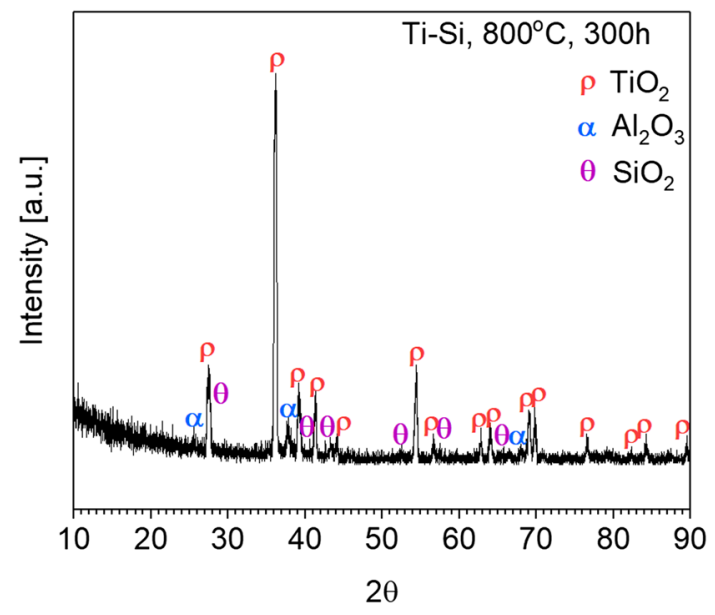

Fig. 8 XRD pattern from the surface of a Ti-Si layer deposited on the Ti-46Al-8Nb (at.\%) substrate after oxidation at $800{ }^{\circ} \mathrm{C}$ for $300 \mathrm{~h}$ (1-h cycles)

The cross sections in Fig. 3 indicate that the Ni-Cr layer was perfectly protective. The scale was very thin, compact and adherent. One troublesome effect was relatively rapid inward diffusion of nickel, which might influence mechanical properties of the alloy. As demonstrated in Fig. 3, Ni diffused preferentially along the darker and thicker lamellas. These are apparently built of $\gamma$-TiAl, constituting $75 \mathrm{~mol} . \%$ in the Ti$46 \mathrm{Al}-8 \mathrm{Nb}$ (at.\%) alloy (thicker lamellas). In order to prevent

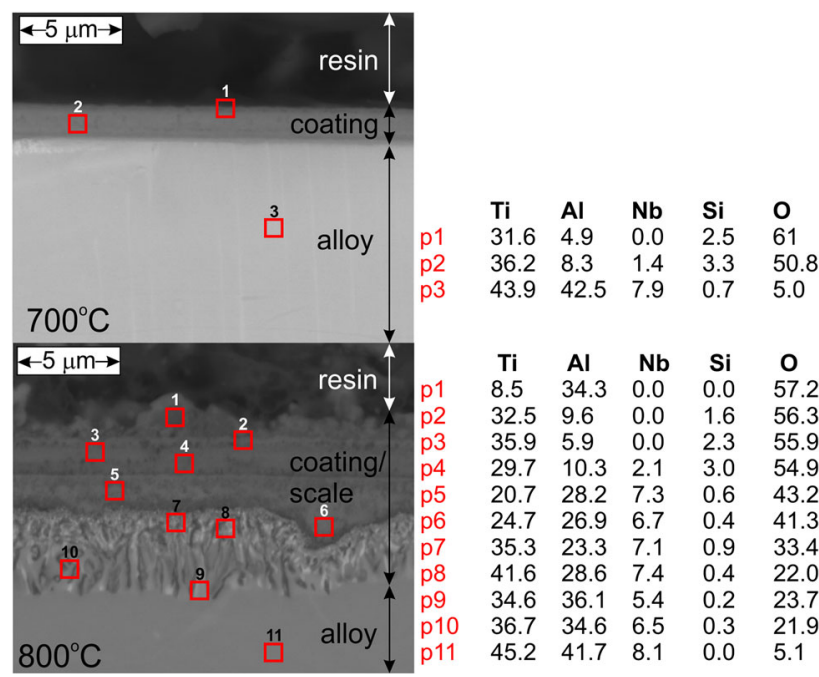

Fig. 9 Micrographs (SEM BEI) of cross sections and local EDS analysis (in at.\%) of the Ti-46Al-8Nb (at.\%) samples with a Ti-Si layer after $80 \mathrm{~h}$ of exposure to air at 700 and $800{ }^{\circ} \mathrm{C}$ (1-h cycles)

the inward diffusion of nickel, an interlayer would be advisable, built of elements having low diffusivity in Ti-Al phases, such as chromium. According to the literature, diffusion of $\mathrm{Ni}$ is faster in $\alpha_{2}-\mathrm{Ti}_{3} \mathrm{Al}$ than in $\gamma$-NiAl (Ref 27). Ni diffusion coefficient at $800{ }^{\circ} \mathrm{C}$ was measured as $8.0 \times 10^{-15} \mathrm{~m}^{2} \mathrm{~s}^{-1}$ in $\alpha_{2}-\mathrm{Ti}_{3} \mathrm{Al}$ (Ref $28)$ and $8.0 \times 10^{-19} \mathrm{~m}^{2} \mathrm{~s}^{-1}$ in $\gamma-\mathrm{TiAl}(\operatorname{Ref} 29)$. On the basis of 
Table 5 Maximum penetration depth $\left(H_{\mathrm{max}}\right)$, Vickers hardness $(\mathrm{HV})$, indentation hardness $\left(H_{\mathrm{IT}}\right)$ and Young's modulus (E) for Ti-46Al-8Nb (at.\%) samples with a Ti-Si layer

\begin{tabular}{lcccc}
\hline Surface condition & $\boldsymbol{H}_{\mathbf{m a x}}, \mathbf{n m}$ & $\mathbf{H V}$ & $\boldsymbol{H}_{\mathbf{I T}}, \mathbf{M P a}$ & $\boldsymbol{E}, \mathbf{G P a}$ \\
\hline Unoxidized & $235 \pm 4$ & $717 \pm 28$ & $7584 \pm 297$ & $164 \pm 2$ \\
Oxidized for $80 \mathrm{~h}$ at $800{ }^{\circ} \mathrm{C}$ & $429 \pm 57$ & $219 \pm 46$ & $2321 \pm 487$ & $100 \pm 23$ \\
\hline
\end{tabular}

Table 6 Critical loads $\left(L_{\mathrm{c} 1}, L_{\mathrm{c} 2}\right)$ and friction coefficient $(\mu)$ in a scratch test for the Ti-46Al-8Nb (at.\%) alloy with a Ti-Si layer (maximum load $P_{\max }=30 \mathrm{~N}$ )

\begin{tabular}{lrr}
\hline Surface condition & $\boldsymbol{L}_{\mathbf{c} 1}, \mathbf{N}$ & $\boldsymbol{L}_{\mathbf{c 2}}, \mathbf{N}$ \\
\hline Unoxidized & $1.2 \pm 0.4^{(1)}$ & \multicolumn{1}{c}{ $\pm 2.3^{(2)}$} \\
Oxidized for $80 \mathrm{~h}$ at $800{ }^{\circ} \mathrm{C}$ & $10.0 \pm 2.5^{(3)}$ & $0.46 \pm 0.05$ \\
& & $0.24 \pm 0.05$ \\
(1) Substrate exposed in some spots & \\
(2) Cracks and delamination around the scratch track & \\
(3) Cohesive cracking inside the scratch track & \\
\hline
\end{tabular}
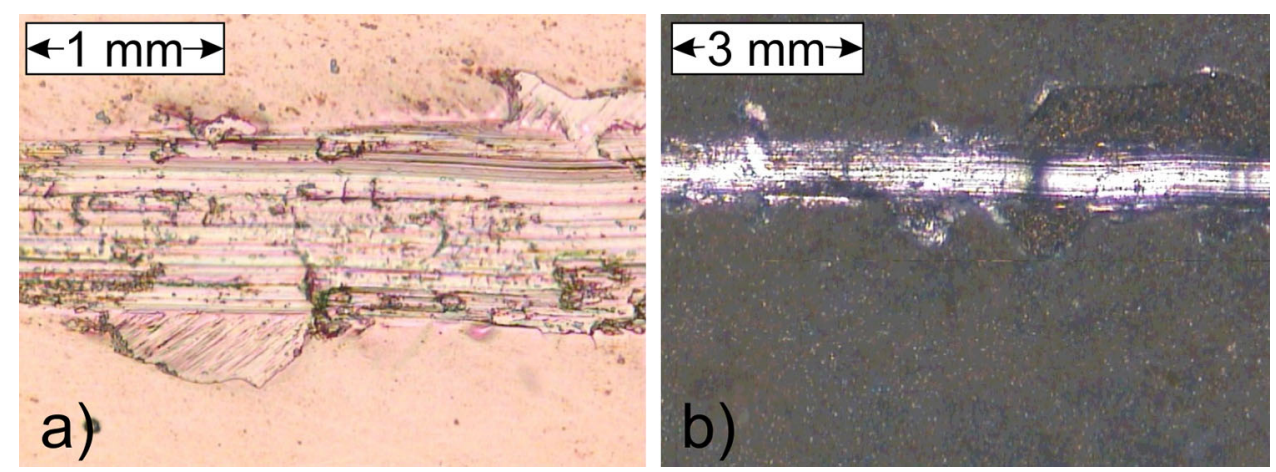

Fig. 10 Scratch tracks (light microscopy) on Ti-Si layers (a) as received and (b) after $80 \mathrm{~h}$ of oxidation at $800{ }^{\circ} \mathrm{C}$

these data, Ni penetration depth in $\alpha_{2}-\mathrm{Ti}_{3} \mathrm{Al}$ and $\gamma$-TiAl would be 50 and $0.5 \mu \mathrm{m}$, respectively, at $800^{\circ} \mathrm{C}$, which by no means are close to the experimental observations. Several plausible explanations can be given to this fact. First of all, the diffusion mechanisms involved may be different. The reported values are the ${ }^{63} \mathrm{Ni}$ isotope diffusion coefficients measured by a radiotracer technique in bulk polycrystalline $\alpha_{2}-\mathrm{Ti}_{3} \mathrm{Al}$ or $\gamma$-TiAl. In this work, the Ti-46Al8Nb (at.\%) alloy contained both phases, with $\gamma$-TiAl being predominant and the ternary addition of niobium, which is known to affect interdiffusion in Ti-Al phases (Ref 30). The lamellar microstructure of the alloy might influence the transport processes (e.g., favor the interlamellar diffusion). Moreover, nickel diffused into the Ti-Al intermetallic alloy from a Ni-Cr layer, so its chemical potential and diffusivity in this layer were different compared with unalloyed nickel. Finally, in the investigated system, reactive diffusion resulted in the formation of ternary intermetallics, so defect structure and transport properties of these intermediate phases might actually be responsible for the growth rate of the interdiffusion zone. From the diffractogram in Fig. 4, it follows that $\mathrm{Ni}-\mathrm{Cr}$ layers sufficiently well-prevented oxidation of the Ti-46A18Nb (at.\%) alloy up to $700{ }^{\circ} \mathrm{C}$, because at $800{ }^{\circ} \mathrm{C} \mathrm{TiO}_{2}$ was already found in the scale (Fig. 4). At the lower temperature, chromium was oxidized preferentially and a protective $\mathrm{Cr}_{2} \mathrm{O}_{3}$ layer was produced on the surface (Fig. 4). Ternary intermetallic, $\mathrm{TiNi}_{2} \mathrm{Al}$, formed as a result of nickel diffusion into the alloy. The $\mathrm{TiNi}_{2} \mathrm{Al}$ $\left(\tau_{4}\right)$ phase has been identified in Ti-Al-Ni alloys at the temperature of $900{ }^{\circ} \mathrm{C}$ (Ref 31,32$)$. It has been also detected as one of the products of interaction between a Ti-Al-based alloy and a Ni-based alloy (type GH99) after heating from 960 to $1040^{\circ} \mathrm{C}$ for 1 to $30 \mathrm{~min}$ in a vacuum furnace (1 MPa) (Ref 33). It should be emphasized that some of Ti-Ni and $\mathrm{Ni}-\mathrm{Al}$ intermetallic phases are known for very good wear and corrosion resistance (Ref 34, 35), so their occurrence in the diffusion zone near the surface might be considered advantageous.

The scale formed at $800{ }^{\circ} \mathrm{C}$ was composed of $\mathrm{Cr}_{2} \mathrm{O}_{3}$ accompanied by $\mathrm{NiO}$ and $\mathrm{NiTiO}_{3}$, indicating some outward diffusion of titanium. On the other hand, $\mathrm{TiO}_{2}$ growth was significantly reduced by the compact layer of $\mathrm{Cr}_{2} \mathrm{O}_{3}$.

\subsection{Ti-Si Layers}

Deposition of Ti-Si layers was motivated by the known positive effect of silicon on the oxidation behavior of titanium alloys (Ref 36, 37). Protective properties of silicon-containing coatings have been also reported in other systems (Ref 38, 39). In the case of $\mathrm{Ti}-\mathrm{Si}$, it was expected that at the beginning of oxidation silicon would react with oxygen to form partly amorphous $\mathrm{SiO}_{2}$, playing a role of barrier against oxygen penetration along the easy diffusion paths (grain boundaries) in the oxide layer. Unfortunately, experimental results did not confirm these expectations. 
It can be concluded from Fig. 9 that at $700{ }^{\circ} \mathrm{C}$ the Ti-Si layer can protect the alloy against oxidation in air. The subjacent alloy remained unchanged (no evidence of phase transformations). Interpretation of EDS analysis in Fig. 9 should be careful because the resolution of this method is not good enough for thin (about $2 \mu \mathrm{m}$ ) layers. Moreover, it is difficult to compare concentrations of light and heavy elements as determined by EDS. It can be derived from the EDS analysis, however, that the scale formed at $700{ }^{\circ} \mathrm{C}$ contained titanium and silicon oxides. It is interesting to note that some amount of aluminum was also present in the surface layer (point $2,700{ }^{\circ} \mathrm{C}$ ), as a result of an outward diffusion of this element from the substrate. The concentration gradient of silicon at the inner interface with the substrate could bring about further inward diffusion of this element, because silicon is known to be the predominant diffuser in the Ti/Si couples (Ref 40).

The temperature of $800{ }^{\circ} \mathrm{C}$ appeared too high for the Ti-Si layer to provide good protection to the alloy. Large $\mathrm{TiO}_{2}$ crystals appeared on its surface after $300 \mathrm{~h}$ of exposure (Fig. 9). As follows from the diffractogram in Fig. 8, titanium dioxide had the structure of rutile. Its growth on the Ti-Si layer was rather fast but it was slower than on pure titanium (Ref 41). For illustration, mass gain of titanium (purity 99.94\%) after $75 \mathrm{~h}$ of oxidation at $800{ }^{\circ} \mathrm{C}$ was about $14 \mathrm{mg} / \mathrm{cm}^{2}$ whereas that of Ti$46 \mathrm{Al}-8 \mathrm{Nb}$ (at.\%) with the Ti-Si layer was about $1 \mathrm{mg} / \mathrm{cm}^{2}$ after the same time. However, the oxidation rate of Ti-46Al-8 $\mathrm{Nb}$ (at. $\%$ ) with the Ti-Si layer was still deemed too high. According to thermodynamic calculations ( $\operatorname{Ref} 42$ ), stable $\mathrm{SiO}_{2}$ scales are formed during oxidation of Ti-Si phases, which contain at least 37.5 at.\% Si. The cross section in Fig. $9\left(800{ }^{\circ} \mathrm{C}\right)$ reveals very complex structure of the near-surface layers. The scale was rather thick (about $10 \mu \mathrm{m}$ ) and composed of two main layers. The inner part (internal oxidation zone) close to the alloy substrate contained aluminum- and niobium-rich precipitates (dark and light spots in SEM BEI in Fig. $9\left(800{ }^{\circ} \mathrm{C}\right)$ ) similarly as in the case of uncoated alloy. These correspond to aluminum oxide and niobium-rich intermetallic. The outer part of the scale was similar to that formed on the Ti-6Al-1Mn (at.\%) alloy after $240 \mathrm{~h}$ of oxidation at $800^{\circ} \mathrm{C}(\operatorname{Ref} 43)$ : thicker layers of titanium dioxide were separated by thinner layers of aluminum oxide. The presence of aluminum in the outer part of the scale indicates an outward diffusion of this element from substrate to the Ti-Si layer.

\subsection{Summary}

The magnetron sputtering technique used in this work had many advantages. Compared with the processes based on diffusional transport, the substrate could be maintained at a relatively low temperature, not exceeding about $300{ }^{\circ} \mathrm{C}$. This prevented changes in alloy microstructure and mechanical properties. Two-component targets used in magnetron sputtering enabled very good control of layer composition. The deposited layers were perfectly compact and adherent. In spite of micrometric thickness, they effectively protected the alloy against gas absorption and oxidation at $700{ }^{\circ} \mathrm{C}$. The oxides ( $\mathrm{NiO}$ and $\mathrm{Cr}_{2} \mathrm{O}_{3}$ ) which formed on the surface of these $\mathrm{Ni}-\mathrm{Cr}$ layers, with major point defects within the cation sublattice could hinder the inward diffusion of oxygen. The nanocrystalline/amorphous $\mathrm{SiO}_{2}$, which accompanied titanium dioxide on the surface of the Ti-Si layer, significantly reduced the growth of $\mathrm{TiO}_{2}$. At $800{ }^{\circ} \mathrm{C}$ the $\mathrm{Ni}-\mathrm{Cr}$ layers only preserved good oxidation resistance. Some small amounts of $\mathrm{TiO}_{2}$ were,
Table 7 Ratios $H_{\mathrm{IT}} / E$ and $H_{\mathrm{IT}}^{3} / E^{2}$ for the Ni-Cr and Ti-Si layers on Ti-46Al-8Nb (at.\%) substrates

\begin{tabular}{lcc}
\hline Surface condition & $\boldsymbol{H}_{\mathbf{I T}} / \boldsymbol{E},-$ & $\boldsymbol{H}_{\mathbf{I T}}^{\mathbf{3}} / \boldsymbol{E}^{\mathbf{2}}, \mathbf{M P a}$ \\
\hline Ni-Cr unoxidized & 0.033 & 7.33 \\
Ni-Cr oxidized for $300 \mathrm{~h}$ at $700{ }^{\circ} \mathrm{C}$ & 0.046 & 14.06 \\
Ni-Cr oxidized for $300 \mathrm{~h}$ at $800{ }^{\circ} \mathrm{C}$ & 0.039 & 17.29 \\
Ti-Si unoxidized & 0.046 & 16.22 \\
Ti-Si oxidized for $80 \mathrm{~h}$ at $800{ }^{\circ} \mathrm{C}$ & 0.023 & 1.25 \\
\hline
\end{tabular}

however, detected in the scale (Fig. 4). $\mathrm{TiO}_{2}$ was the predominant phase on the surface of Ti-Si layers (Fig. 8).

The Ni-Cr and Ti-Si layers on a Ti-46Al8Nb (at.\%) differed in micromechanical properties. The highest indentation hardness $(11.1 \mathrm{GPa})$ was measured for the Ni-Cr layer after $80 \mathrm{~h}$ of oxidation in air at $800{ }^{\circ} \mathrm{C}$ (Table 3$)$. The lowest value (2.3 GPa) was found for Ti-Si oxidized in the same conditions (Table 5). In the case of Young's modulus $(E)$, very low values (good ductility) were calculated for the Ti-Si layer after oxidation at $800^{\circ} \mathrm{C}$ (Table 5) and for the Ni-Cr layer after oxidation at $700^{\circ}$ C. This can be ascribed to the fine-grained structure of the scale. The resistance to plastic deformation and crack propagation can be evaluated on the basis of the ratios: $H_{\mathrm{IT}} / E$ and $H_{\mathrm{IT}}^{3} / E^{2}$ (Ref 44). The higher the value of $H_{\mathrm{IT}} / E$ and $H_{\mathrm{IT}}^{3} / E^{2}$, the better the wear resistance. The $H_{\mathrm{IT}} / E$ and $H_{\mathrm{IT}}^{3} / E^{2}$ ratios of the investigated samples are collected in the Table 7.

The H/E ratio of the Ti-Si layer before oxidation was higher than that of Ni-Cr, and it decreased to one-half of the original value after oxidation at $800{ }^{\circ} \mathrm{C}$. In the case of Ni-Cr layers, the $\mathrm{H} / \mathrm{E}$ value was higher for the oxidized samples. Adhesion of the coating is another very important parameter, which could be estimated from the scratch test (Tables 4 and 6). Before oxidation the $\mathrm{Ni}-\mathrm{Cr}$ layers had better properties compared with Ti-Si, the critical loads for cohesive $\left(L_{\mathrm{c} 1}\right)$ and adhesive $\left(L_{\mathrm{c} 2}\right)$ failure were equal to $10.6 \mathrm{~N}$ and more than $30 \mathrm{~N}$, respectively (Table 3). It should be mentioned that the critical load for adhesive failure of about $30-40 \mathrm{~N}$ is typical for TiN layers deposited on cutting tools (Ref 45). After oxidation at 700 and $800{ }^{\circ} \mathrm{C}$ the $L_{\mathrm{c} 1}$ and $L_{\mathrm{c} 2}$ values for the $\mathrm{Ni}-\mathrm{Cr}$ layers were lower but still relatively high. According to Table 6, the Ti-Si layer had definitely worse properties. The values of friction coefficient collected in Tables 4 and 6 indicate that the surface of Ni$\mathrm{Cr}$ layers was smooth and could have satisfactory anti-wear and anti-friction properties. The friction coefficient of about 0.2 for the Ni-Cr layers (Table 4) was similar to the values reported for the Ni-25Cr coatings deposited on cast iron (Ref 46).

\section{Conclusions}

1. The Ni-Cr and Ti-Si layers provided good protection of the Ti-46Al-8Nb (at.\%) alloy against gas absorption and oxidation at $700{ }^{\circ} \mathrm{C}$.

2. The Ni-Cr layer effectively prevented gas penetration and significantly limited $\mathrm{TiO}_{2}$ growth at $800{ }^{\circ} \mathrm{C}$ owing to the formation of a protective $\mathrm{Cr}_{2} \mathrm{O}_{3}$ scale.

3. Relatively fast inward diffusion of nickel to the subjacent alloy, especially at elevated temperatures, is considered some drawback of the proposed protective system based 
on the oxidation properties of the Ni-Cr alloys. This issue calls for further studies with a focus on mechanical properties and oxidation behavior in a long-term test.

\section{Acknowledgment}

The authors gratefully acknowledge financial support from AGH-UST statutory funds (badania statutowe: 11.11.160.438) and as well as valuable contributions of Dr. S. Zimowski, Dr. M. Kot and Dr. R. Mania to the measurements of micromechanical properties and coating deposition.

\section{Open Access}

This article is distributed under the terms of the Creative Commons Attribution 4.0 International License (http:// creativecommons.org/licenses/by/4.0/), which permits unrestricted use, distribution, and reproduction in any medium, provided you give appropriate credit to the original author(s) and the source, provide a link to the Creative Commons license, and indicate if changes were made.

\section{References}

1. K. Kothari, R. Radhakrishnan, and N.M. Wereley, Advances in Gamma Titanium Aluminides and Their Manufacturing Techniques, Prog. Aerosp. Sci., 2012, 55, p 1-16

2. M. Thomas and M.-P. Bacos, Processing and Characterization of TiAl Based Alloys: Towards an Industrial Scale, Onera Aerosp. Lab., 2011, 3, p 1-11

3. X. Wu, Review of Alloy and Process Development of TiAl Alloys, Intermetallics, 2006, 14, p 1114-1122

4. M. Blum, G. Jarczyk, H. Scholz, S. Pleier, P. Busse, H.-J. Laudenberg, K. Segtrop, and R. Simon, Prototype Plant for the Economical Mass Production of TiAl-Valves, Mater. Sci. Eng., 2002, A329-331, p 616-620

5. V. Lupinc, M. Marchionni, G. Onofrio, M. Nazmy, M. Staubli, B. Phillipsen, and K.-H. Rohne, Processing and Properties of $\gamma$-TiAl for Turbocharger and Power Plant Applications, Steels and Materials for Power Plants, P. Neumann, D. Allen, and E. Teuckhoff, Ed., WileyVCH Verlag GmbH, London, 2006, p 327-331

6. A. Lasalmonie, Intermetallics: Why Is It So Difficult to Introduce Them in Gas Turbine Engines?, Intermetallics, 2006, 14, p 1123-1129

7. Z.B. Jiao, J.H. Luan, and C.T. Liu, Strategies for Improving Ductility of Ordered Intermetallics, Prog. Nat. Sci.-Mater., 2016, 26, p 1-12

8. G. Meier, F. Pettit, and S. Hu, Oxidation Behavior of Titanium Aluminides, J. de Phys. IV Colloq., 1993, 03(C9), p 395-402

9. X. Wu, A. Huang, D. Hu, and M.H. Loretto, Oxidation-Induced Embrittlement of TiAl Alloys, Intermetallics, 2009, 17, p 540-552

10. S.L. Draper and D. Isheim, Environmental Embrittlement of a Third Generation g TiAl Alloy, Intermetallics, 2012, 22, p 77-83

11. G. Schumacher, F. Dettenwanger, M. Schütze, U. Hornauer, E. Richter, E. Wieser, and W. Möller, Microalloying Effects in the Oxidation of TiAl Materials, Intermetallics, 1999, 7, p 1113-1120

12. R. Pflumm, S. Friedle, and M. Schütze, Oxidation Protection of g-TiAlBased Alloys: A Review, Intermetallics, 2015, 56, p 1-14

13. Zhang Dongbo, Song Guanyu, Xue Zhiyong, Jia Long, and Xu Gang, NiAlHf Coating on TiAl Substrate Prepared by EB-PVD, Rare Metal Mat. Eng., 2014, 43(11), p 2657-2662

14. H. Zhang, X. Peng, and F. Wang, Fabrication of an Oxidation-Resistant $\beta$-NiAl Coating on $\gamma$-TiAl, Surf. Coat. Technol., 2012, 206, p 2454 2458

15. A. Ebach-Stahl and M. Fröhlich, Oxidation Study of Pt-Al Based Coatings on $\gamma$-TiAl at $950{ }^{\circ} \mathrm{C}$, Surf. Coat. Technol., 2016, 287, p 20-24

16. J. Cizek, O. Man, P. Roupcova, K. Loke, and I. Dlouhy, Oxidation Performance of Cold Spray Ti-Al Barrier Coated $\gamma$-TiAl Intermetallic Substrates, Surf. Coat. Technol., 2015, 268, p 85-89
17. M. Mitoraj-Królikowska and E. Godlewska, Oxidation Resistance and Micromechanical Properties of a Ti-46Al-8Nb (at.\%) Alloy with Cr-Si Magnetron-Sputtered Coatings, Surf. Coat. Technol., 2018, 350, p 732-739

18. S.L. Lee, M. Cipollo, F. Yee, R. Wei, K. Coulter, J. Lin, W. Sproul, J.J. Moore, Deposition of Environmental Friendly Tantalum and Chromium Nitride Coatings Using HIPIMS-MPP-PEMS Technologies, 53rd Annual Technical Conference Proceedings, 2010, p 125-133

19. M. Mitoraj, E. Godlewska, O. Heintz, N. Geoffroy, S. Fontana, and S. Chevalier, Scale Composition and Oxidation Mechanism of the Ti-46Al-8Nb Alloy in Air at 700 and $800{ }^{\circ} \mathrm{C}$, Intermetallics, 2011, 19, p 39-47

20. E. Godlewska, M. Mitoraj, and J. Morgiel, Reaction and Diffusion Phenomena Upon Oxidation of a $\left(\gamma+\alpha_{2}\right)$ TiAlNb Alloy in Air, Mater. High Temp., 2009, 26(1), p 99-103

21. E. Godlewska, M. Mitoraj, F. Devred, and B.E. Nieuwenhuys, Reactivity of $459 \mathrm{Al}-8 \mathrm{Nb}$ Alloy in Air at $700-900^{\circ} \mathrm{C}, \mathrm{J}$. Therm. Anal. Calorim., 2007, 88(1), p 225-230

22. N.F. Ak, C. Tekmen, I. Ozdemir, H.S. Soykan, and E. Celik, NiCr Coatings on Stainless Steel by HVOF Technique, Surf. Coat. Technol., 2003, 174-175, p 1070-1073

23. I. Cvijović, M.T. Jovanović, and D. Peruško, Cyclic Oxidation Behaviour of $\mathrm{Ti}_{3} \mathrm{Al}$-Based Alloy with Ni-Cr Protective Layer, Corros. Sci., 2008, 50, p 1919-1925

24. G.C. Wood and T. Hodgkiess, Characteristic Scales on Pure NickelChromium Alloys at $800-1200^{\circ} \mathrm{C}$, J. Electrochem. Soc., 1966, 113(4), p 319-327

25. H.V. Atkinson, A Review of the Role of Short-Circuit Diffusion in the Oxidation of Nickel, Chromium, and Nickel-Chromium Alloys, Oxid. Met., 1985, 24(3/4), p 177-197

26. Dong-Bo Wei, Ping-Ze Zhang, Zheng-Jun Yao, Xiang-Fei Wei, JinTang Zhou, and Xiao-Hu Chen, Preparation and High-Temperature Oxidation Behavior Of Plasma Cr-Ni Alloying on Ti6Al4 V Alloy Based on Double Glow Plasma Surface Metallurgy Technology, Appl. Surf. Sci., 2016, 388, p 571-578

27. C. Herzig, T. Przeorski, M. Friesel, F. Hisker, and S. Divinski, Tracer Solute Diffusion of $\mathrm{Nb}, \mathrm{Zr}, \mathrm{Cr}, \mathrm{Fe}$, and $\mathrm{Ni}$ in g-TiAl: Effect of Preferential Site Occupation, Intermetallics, 2001, 9, p 461-472

28. J. Breuer, T. Wilger, M. Friesel, and C. Herzig, Interstitial and Substitutional Diffusion of Metallic Solutes in $\mathrm{Ti}_{3} \mathrm{Al}$, Intermetallics, 1999, 7, p 381-388

29. T. Przeorski, M. Friesel, F. Hisker, S.V. Divinski, C. Herzig, Solute Diffusion in the Intermetallic Compound $\gamma$-TiAl, Deffect and Diffusion Forum, 2001, 194-199, p 493-498

30. S. Divinski, F. Hisker, C. Klinkenberg, and C. Herzig, Niobium and Titanium Diffusion in the High Niobium-Containing Ti-54Al-10Nb Alloy, Intermetallics, 2006, 14, p 792-799

31. B. Huneau, P. Rogl, K. Zeng, R. Schmid-Fetzer, M. Bohn, and J. Bauer, The Ternary System Al-Ni-Ti Part I: Isothermal Section at $900^{\circ}$ $\mathrm{C}$; Experimental Investigation and Thermodynamic Calculation, Intermetallics, 1999, 7, p 1337-1345

32. A.U. Khan, X. Yan, P. Rogl, and A. Saccone, On the Four-Phase Reactions in the Ti-Ni-Al System, Intermetallics, 2009, 17, p 1000-1006

33. Li Hai-xin, He Peng, Lin Tie-song, Pan Feng, Feng Ji-cai, and Huang Yu-dong, Microstructure and Shear Strength of Reactive Brazing Joints of TiAl/Ni-Based Alloy, Trans. Nonferrous Met. Soc. China, 2012, 22, p 324-329

34. Q.S. Lin, K.S. Zhou, C.M. Deng, M. Liu, L.P. Xu, and C.G. Deng, Deposition Mechanisms and Oxidation Behaviors of Ti-Ni Coatings Deposited in Low-Temperature HVOF Spraying Process, J. Therm. Spray. Technol., 2014, 26(3), p 892-902

35. Y.I. Evdokimenko, V.M. Kisel, S.V. Buchakov, A.A. Rogozinskaya, D. Z. Yurchenko, and R.V. Litvin, Properties of Intermetallic Ni-Al Coatings Deposited by High-Velocity Air-Fuel Spraying, Powder Metall. Metal., 2011, 49(11-12), p 660-666

36. A.M. Chaze and C. Coddet, Influence of Silicon on the Oxidation of Titanium Between 550 and $700{ }^{\circ} \mathrm{C}$, Oxid. Met., 1987, 27(1-2), p 120

37. D. Vojtěch, H. Č́ižová, K. Jurek, and J. Maixner, Influence of Silicon on High-Temperature Cyclic Oxidation Behaviour of Titanium, $J$. Alloy. Compd., 2005, 394, p 240-249

38. H.-P. Xiong, W. Mao, Y.-H. Xie, Y.-Y. Cheng, and X.-H. Li, Formation of Silicide Coatings on the Surface of a TiAl-Based Alloy and Improvement in Oxidation Resistance, Mater. Sci. Eng.: A, 2005, 391, p $10-18$ 
39. X.Y. Li, S. Taniguchi, Y. Matsunaga, K. Nakagawa, and K. Fujita, Influence of Siliconizing on the Oxidation Behavior of a g-TiAl Based Alloy, Intermetallics, 2003, 11, p 143-150

40. J. Chang, G.B. Kim, D.-S. Yoon, H.K. Baik, D.-J. Yoo, and S.-M. Lee, Investigation of the Mechanism of Titanium Silicide Reaction Using Ion-Beam-Assisted Deposition, Appl. Phys. Lett., 1999, 75(19), p 2900-2902

41. P. Kofstad, P.B. Anderson, and O.J. Krudtaa, Oxidation of Titanium in the Temperature Range 800-1200 ${ }^{\circ} \mathrm{C}$, J. Less-Common Met., 1961, 3, p 89-97

42. B.V. Cockeram and R.A. Rapp, The Kinetics of Multilayered TitaniumSilicide Coatings Grown by the Pack Cementation Method, Metall. Mater. Trans. A, 1996, 26(4), p 777-791

43. E. Godlewska, M. Mitoraj, and B. Jajko, Oxidation of Some Titanium Alloys in Air at Elevated Temperatures, Mater. Sci. Forum, 2008, 595598, p 967-974
44. Wangyang Ni, Yang-Tse Cheng, Michael J. Lukitsch, Anita M. Weiner, Lenoid C. Lev, and David S. Grummon, Effects of the Ratio of Hardness to Young's Modulus on the Friction and Wear Behaviour of Bilayer Coatings, Appl. Phys. Lett., 2004, 85, p 4028-4030

45. J. Valli, U. Mäkelä, A. Matthews, and V. Murawa, TiN Coating Adhesion Studies Using the Scratch Test Method, J. Vac. Sci. Technol., 1985, A3, p 2411-2414

46. Z. Minlin, L. Wenjin, and Z. Hongjun, Corrosion and Wear Resistance Characteristics of $\mathrm{NiCr}$ Coating by Laser Alloying with Powder Feeding on Grey Iron Liner, Wear, 2006, 260, p 1349-1355

Publisher's Note Springer Nature remains neutral with regard to jurisdictional claims in published maps and institutional affiliations. 